\title{
Brucella pinnipedialis in hooded seal (Cystophora cristata) primary epithelial cells
}

Anett Kristin Larsen ${ }^{1,2^{*}}$, Jacques Godfroid ${ }^{1,2}$ and Ingebjørg Helena Nymo ${ }^{1,2}$

\begin{abstract}
Background: Marine Brucella spp. have been isolated from numerous pinniped and cetacean species, but pathological findings in association with infection with Brucella pinnipedialis in pinnipeds have been sparse. The capacity of brucellae to survive and replicate within host macrophages underlies their important ability to produce chronic infections, but previous work has shown that B. pinnipedialis spp. are rapidly eliminated from hooded seal (Cystophora cristata) alveolar macrophages.
\end{abstract}

Results: To investigate if multiplication could take place in other hooded seal cell types, primary epithelial cells were isolated, verified to express the epithelial marker cytokeratin and challenged with three different strains of B. pinnipedialis; B. pinnipedialis sp. nov., B. pinnipedialis hooded seal strain B17, and B. pinnipedialis hooded seal strain 22F1. All strains were steadily eliminated and the amounts of intracellular bacteria were reduced to less than one-third by $48 \mathrm{~h}$ post infection. Intracellular presence was verified using immunocytochemistry.

Conclusions: So far, intracellular multiplication in seal cells has not been documented for B. pinnipedialis. The lack of intracellular survival in macrophages, as well as in epithelial cells, together with the fact that pathological changes due to B. pinnipedialis infection is not yet identified in seals, suggests that the bacteria may only cause a mild, acute and transient infection. These findings also contribute to substantiate the hypothesis that seals may not be the primary host of $B$. pinnipedialis and that the transmission to seals are caused by other species in the marine environment.

Keywords: Brucella pinnipedialis, Epithelial cells, Hooded seal, Infection, In vitro, Marine ecosystem, Pinnipeds, Spillover

\section{Findings}

Brucella spp. were first isolated from marine mammals in 1994 [1] and were validly published as the species Brucella pinnipedialis sp. nov. and Brucella ceti sp. nov. in 2007 [2]. The bacteria have been isolated from numerous organs in pinniped and cetacean species, but pathological findings in association to infection with $B$. pinnipedialis in pinnipeds has only once been reported in eared seals (otariids) [3] and never, to date, in true seals. In dolphins, however, B. ceti have been shown to cause pathology in the central nervous system and the reproductive system $[4,5]$.

\footnotetext{
*Correspondence: anett.k.larsen@uit.no

2 Fram Centre, High North Research Centre for Climate and the

Environment, 9007 Tromsø, Norway

Full list of author information is available at the end of the article
}

The capacity of brucellae to survive and replicate within host macrophages underlies their important ability to produce chronic infections [6], yet in vitro work has revealed that $B$. pinnipedialis hooded seal (HS) strain and B. pinnipedialis sp. nov. do not multiply in murine or human macrophage cell lines [7]. Brucellae are shown to exhibit a host preference [8], however, in vitro work with B. pinnipedialis HS strain, B. pinnipedialis sp. nov., B. ceti sp. nov., and B. ceti Atlantic white-sided dolphin (Lagenorhynchus acutus) strain in HS primary macrophages revealed no multiplication [9]. Brucella spp. may invade many cell types [10], but B. pinnipedialis HS strain and $B$. pinnipedialis sp. nov. were likewise rapidly eliminated from a human epithelial cell line [7]. The aim of the current study is to investigate whether $B$. pinnipedialis multiply in primary epithelial cells from HS.

\section{Biomed Central}

(c) 2016 Larsen et al. This article is distributed under the terms of the Creative Commons Attribution 4.0 International License (http://creativecommons.org/licenses/by/4.0/), which permits unrestricted use, distribution, and reproduction in any medium, provided you give appropriate credit to the original author(s) and the source, provide a link to the Creative Commons license, and indicate if changes were made. The Creative Commons Public Domain Dedication waiver (http://creativecommons.org/ publicdomain/zero/1.0/) applies to the data made available in this article, unless otherwise stated. 
The Brucella strains used were B. pinnipedialis sp. nov. (NCTC $12890^{\mathrm{T}}, \mathrm{BCCN} 94-73^{\mathrm{T}}$ ) [2] and two B. pinnipedialis HS isolates (spleen B17, and lung 22F1) [11]. The strains were kept and handled, and the final infective solutions were prepared, as previously described [7].

Epithelial tissue was collected from esophagus post mortem on two HSs (the same animals as previously described [9]). Approval of capture and import of animals was given by the appropriate authorities, and all animal use was in accordance with the Norwegian Animal Welfare Act and the regulations for use of animals in experimentation (permit no. 2402). Tissue cultures were prepared according to published protocols [12], and cultured in RPMI 1640, 10 \% fetal bovine serum, $100 \mathrm{IU} / \mathrm{ml}$ penicillin, and $100 \mu \mathrm{g} / \mathrm{ml}$ streptomycin at $37{ }^{\circ} \mathrm{C}, 5 \% \mathrm{CO}_{2}$.

The epithelial origin of the cell culture was verified by immunocytochemistry using the epithelial marker cytokeratin. Adherent cells were fixed for $15 \mathrm{~min}$ at room temperature using $4 \%$ paraformaldehyde $(0.02 \mathrm{M}$ sucrose, $\mathrm{pH}$ 7.2) and washed once in phosphate-buffered saline (PBS). Immune labeling was performed using mouse anti-pan cytokeratin antibody (PCK-26, SigmaAldrich, St. Louis, USA, 1:100). Secondary antibody was Alexa Fluor 546 goat anti-mouse IgG (Molecular Probes, Life Technologies, Paisley, UK, 1:500). For verification of intracellular bacterial localization, epithelial cells were challenged with $B$. pinnipedialis HS strain B17 as described in the gentamicin protection assay. Immune labeling was done using rabbit polyclonal anti-Brucella antibody, 1:100 (Prof. J.J. Letesson). Secondary antibody was Alexa Fluor 488 goat anti-rabbit IgG (Molecular Probes, 1:500). The fluorescent DNA dye DRAQ5 (Cell Signaling, Danvers, USA, 1:1000) was used for visualization of nuclei.

Primary HS epithelial cells were seeded $\left(10^{5}\right.$ cells/well $)$ in 24 well plates and cultured for 8 days prior to infection. The cells were challenged as previously described for HeLa cells [7] and incubated for 1.5, 7, 24, and $48 \mathrm{~h}$. Harvesting of cells and plating for evaluation of the number of intracellular bacteria were as previously described [7].

After 8 days in culture the majority of the cells expressed the epithelial marker cytokeratin as illustrated by the anti-pan cytokeratin staining (Fig. 1). At day 12 the cultures contained a large amount of cells with a fibroblast-like morphology staining negative for anti-pan cytokeratin. Bacterial challenge was thus performed after 8 days in culture to ensure that the correct cell type was evaluated.

The results from the gentamicin protection assay revealed that all $B$. pinnipedialis strains were able to enter HS epithelial cells in vitro. When challenging the cells with a MOI of 500, B. pinnipedialis HS strains B17 and 22F1, and B. pinnipedialis sp. nov. showed moderate ability to enter, yielding log CFUs of 3.16, 2.87 and 2.82 at $1.5 \mathrm{~h}$ post infection (pi), respectively (Fig. 2). All three B. pinnipedialis strains were steadily eliminated and by $24 \mathrm{~h}$ pi the retrieved CFUs were reduced with 1.05-1.39 $\log$ CFUs. By $48 \mathrm{~h}$ pi, the amount of intracellular bacteria were reduced to less than one-third of the numbers of CFU at $1.5 \mathrm{~h} \mathrm{pi,} \mathrm{yielding} \log$ CFUs of $0.66,0.89$ and 0.72 . No significant differences (Student's $t$ test, $P<0.05$ was considered significant) could be detected and the pattern of entry and elimination was similar for the three strains investigated (Fig. 2).

The intracellular localization of $B$. pinnipedialis $\mathrm{HS}$ strain B17 was confirmed by confocal microscopy (Fig. 3). Double immune labeling with anti-Brucella antibody and anti-pan cytokeratin antibody revealed intracellular presence of bacteria in cells staining positive for the epithelial marker.

For the first time, we present the results of infecting HS epithelial cells with $B$. pinnipedialis HS strain in vitro. Compiled with existing information from field research and in vitro macrophage infection assays, our results contribute to further understanding of marine Brucella infections in seals, a condition where epidemiology, pathogenesis and clinical importance are still unclear.

Brucella pinnipedialis HS strain seems to have a restricted, if any, ability to establish chronicity as the bacteria fail to multiply intracellularly in human and murine macrophages $[7,13]$. The low pathogenicity of HS B. pinnipedialis has also been confirmed in a mouse model of infection [14]. Little information is available regarding the pathogenicity of these bacterial strains in seals, which are assumed to be the natural hosts of $B$. pinnipedialis, and the ability of the marine mammal brucellae to enter and multiply in host cells has been largely unexplored.

In addition to trophoblasts, which are target cells in the female reproductive organ, interaction with different cell types are shown for the pathogenic terrestrial brucellae. Macrophages are believed to be preferred as long time survival in the mononuclear phagocyte system of spleen, liver and bone marrow will sustain a chronic infection [6]. Brucella pinnipedialis HS isolate B17 and sp. nov. are previously shown to enter HS alveolar macrophages, but are rapidly eliminated [9]. As HSs are believed to be the primary host of $B$. pinnipedialis $\mathrm{HS}$ strain, it is intriguing that the HS isolate were not able to multiply in macrophages. In this work we aimed to explore if multiplication could take place in primary epithelial cells from a tentative host species, as shown for terrestrial pathogenic brucellae [15]. Epithelial cells would be the first cell type encountered given an exposure route through the food web, and both fish [16] or invertebrates, and possibly lungworms $[17,18]$, may be involved in transmission 

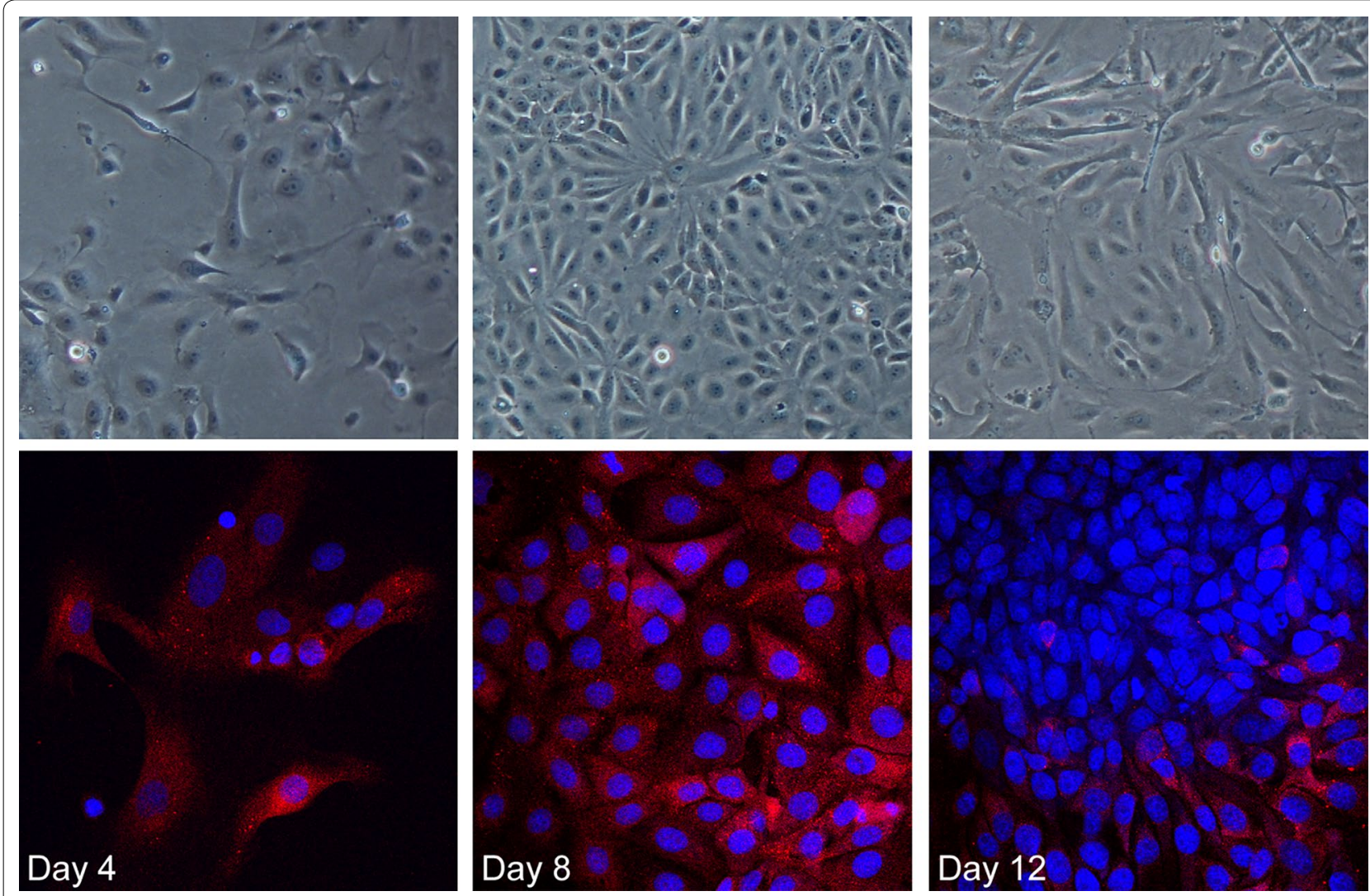

Fig. 1 Verification of the identity of epithelial cells. Cultures of hooded seal primary epithelial cells staining positive for the epithelial marker cytokeratin (red). Images from confocal microscopy shown together with similar areas in light microscopy showing cell morphology at day 4,8 and 12 after initiation of culture

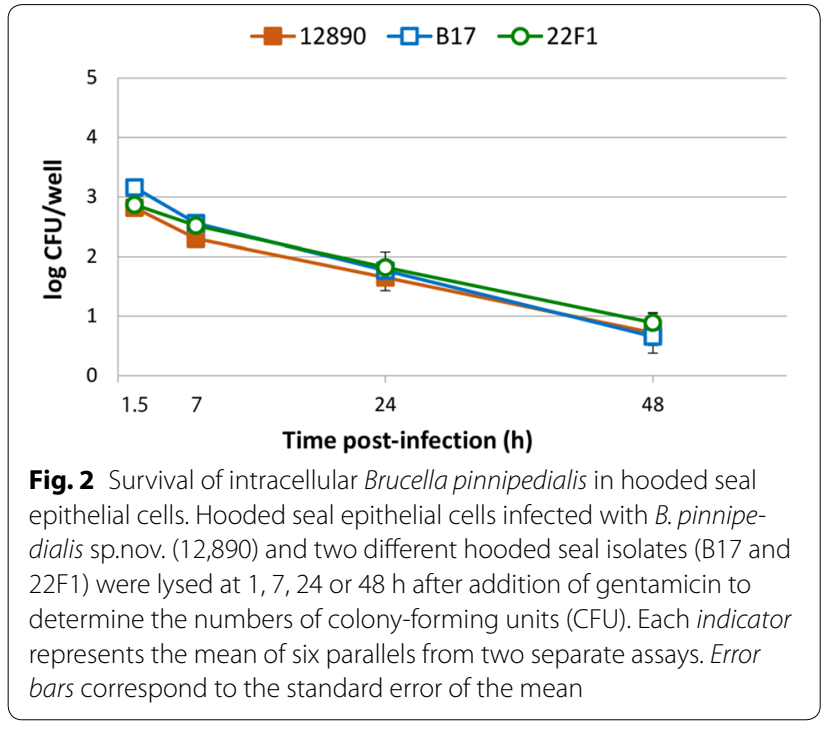

of marine brucellae. Although intracellular bacteria were not eliminated as quickly as reported for HS alveolar macrophages, the amount of viable intracellular bacteria steadily decreased during $48 \mathrm{~h}$ pi and no multiplication was detected. Entry of HS epithelial cells by B. pinnipedialis HS strain was verified by confocal microscopy, where intracellular bacteria were detected within cells staining positive for the epithelial marker (Fig. 3).

One can only speculate whether other cell types could be the target of $B$. pinnipedialis infection, supporting intracellular survival and multiplication. Brucella abortus is shown to survive within murine and human B-cells $[19,20]$ creating an intracellular niche that contributes to a chronic infection. Specific subpopulations of peripheral blood mononuclear cells (PBMCs) are not yet identified in the HS, however preliminary results indicate that $B$. pinnipedialis HS strain is quickly eliminated from infected HS PBMCs, reaching lysosomal compartments already at $1 \mathrm{~h}$ pi (Larsen, unpublished results). In light of the unusual high hematocrit found in hooded seals [21], erythrocytes could be a target for infection, as shown for B. melitensis in mice [22].

The lack of intracellular survival, together with the fact that pathological changes due to $B$. pinnipedialis infection is not yet identified in true seals, suggests that the 


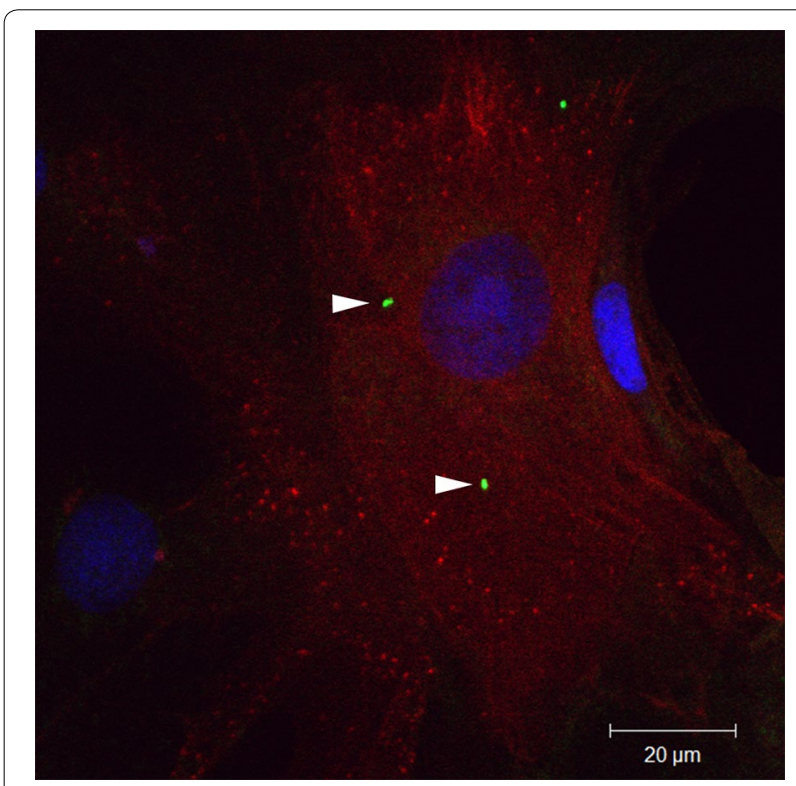

Fig. 3 Intracellular localization of Brucella pinnipedialis hooded seal strain. Double immune labeling with anti-Brucella antibody (green) and anti-pan cytokeratin antibody (red) confirmed intracellular presence of hooded seal B. pinnipedialis strain B17 (arrowheads) in hooded seal epithelial cells. Scale bar $20 \mu \mathrm{m}$. The confocal image is a single optical section of $0.5 \mu \mathrm{m}$ captured perpendicular to the Z-axis at the level of the nucleus using a Zeiss LSM510 META system (Carl Zeiss, Obercochen, Germany) equipped with a 40X 1.2NA water immersion lens

bacteria cause a mild acute and transient infection. Given that $B$. pinnipedialis is unable to multiply intracellularly in macrophages and epithelial cells derived from other seal species, we argue that seals may not be the primary host for B. pinnipedialis, but rather a "dead-end" or spillover host being susceptible to infection transmitted from other hosts in the marine environment. Age-dependent serological and bacteriological patterns for $B$. pinnipedialis have been identified in HSs with a low probability of being positive for pups, a high probability for yearlings, followed by a decreasing probability with age, suggesting an environmental exposure post weaning during the first year of life followed by clearance of infection before the age of reproduction [23]. A similar age-dependent pattern of anti-Brucella antibodies was also identified in harbor seals $[24,25]$. This raises the question of a reservoir of $B$. pinnipedialis in the food web, a hypothesis that is strengthened by the results presented herein and warrants further investigations.

\section{Authors' contributions}

IHN and AKL drafted the manuscript. AKL isolated hooded seal primary epithelial cells and performed the in vitro cell work. JG, IHN and AKL participated in the study design and provided critical evaluation of the manuscript. All authors have read and approved the final manuscript.

\section{Author details}

${ }^{1}$ Department of Arctic and Marine Biology, Faculty of Biosciences, Fisheries and Economics, University of Troms $\varnothing$ - The Arctic University of Norway, 9037 Tromsø, Norway. ${ }^{2}$ Fram Centre, High North Research Centre for Climate and the Environment, 9007 Tromsø, Norway.

\section{Acknowledgements}

Rabbit polyclonal anti-Brucella antibody was kindly provided by Prof. J.J. Letesson, Université de Namur, Belgium. The B. pinnipedialis sp. nov. (NCTC 12890', BCCN 94-73') was a kind gift from Geoffrey Foster, Scottish Agricultural College, Consulting Veterinary Services, Inverness, Scotland. Confocal microscopy was performed at the UNN/UiT Bioimaging platform, University of Tromsø, Norway.

\section{Competing interests}

The authors declare that they have no competing interests.

Received: 23 October 2015 Accepted: 12 January 2016

Published online: 25 January 2016

\section{References}

1. Ross HM, Foster G, Reid RJ, Jahans KL, MacMillan AP. Brucella species infection in sea-mammals. Vet Rec. 1994;134:359.

2. Foster G, Osterman BS, Godfroid J, Jacques I, Cloeckaert A. Brucella ceti sp. nov. and Brucella pinnipedialis sp. nov. for Brucella strains with cetaceans and seals as their preferred hosts. Int J Syst Evol Microbiol. 2007;57:2688-93.

3. Duncan CG, Tiller R, Mathis D, Stoddard R, Kersh GJ, Dickerson B, et al. Brucella placentitis and seroprevalence in northern fur seals (Callorhinus ursinus) of the Pribilof Islands, Alaska. J Vet Diagn Invest. 2014;26:507-12.

4. Guzman-Verri C, Gonzalez-Barrientos R, Hernandez-Mora G, Morales JA, Baquero-Calvo E, Chaves-Olarte E, et al. Brucella ceti and brucellosis in cetaceans. Front Cell Infect Microbiol. 2012;2:3.

5. Nymo $\mathbf{H}$, Tryland M, Godfroid J. A review of Brucella infection in marine mammals, with special emphasis on Brucella pinnipedialis in hooded seal (Cystophora cristata). Vet Res. 2011;42:93.

6. Roop RM, Gaines JM, Anderson ES, Caswell CC, Martin DW. Survival of the fittest: how Brucella strains adapt to their intracellular niche in the host. Med Microbiol Immunol. 2009;198:221-38.

7. Larsen AK, Nymo IH, Briquemont B, Sorensen KK, Godfroid J. Entrance and survival of Brucella pinnipedialis hooded seal strain in human macrophages and epithelial cells. PLoS One. 2013;8:e84861. doi:10.1371/ journal.pone.0084861.

8. Corbel M, Banai M. Genus Brucella Meyer and Shaw 1920. In: Garrity GM, Krieg NR, Staley JT, James T, editors. Bergey's Manual of Systematic Bacteriology. 2nd ed. New York: Springer; 2005. p. 370-85.

9. Larsen AK, Nymo IH, Boysen P, Tryland M, Godfroid J. Entry and elimination of marine mammal Brucella spp. by hooded seal (Cystophora cristata) alveolar macrophages in vitro. PLoS One. 2013;8:e70186. doi:10.1371/ journal.pone.0070186.

10. von Bargen K, Gorvel JP, Salcedo SP. Internal affairs: investigating the Brucella intracellular lifestyle. FEMS Microbiol Rev. 2012;36:533-62.

11. Tryland M, Sorensen KK, Godfroid J. Prevalence of Brucella pinnipediae in healthy hooded seals (Cystophora cristata) from the North Atlantic Ocean and ringed seals (Phoca hispida) from Svalbard. Vet Microbiol. 2005;105:103-11.

12. Ian Freshney R. Specialized cells. In: Hoboken NJ, editor. Culture of animal cells: a manual of basic technique and specialized applications. 6 th ed. Wiley; 2010. p. 383-432.

13. Maquart M, Zygmunt MS, Cloeckaert A. Marine mammal Brucella isolates with different genomic characteristics display a differential response when infecting human macrophages in culture. Microb Infect. 2009;11:361-6.

14. Nymo IH, das Neves CG, Tryland M, Bardsen BJ, Santos RL, Turchetti AP, et al. Brucella pinnipedialis hooded seal (Cystophora cristata) strain in the mouse model with concurrent exposure to PCB 153. Comp Immunol Microbiol Infect Dis. 2014;37:195-204. 
15. Pizarro-Cerda J, Meresse S, Parton RG, van der Goot G, Sola-Landa A, Lopez-Goni I, et al. Brucella abortus transits through the autophagic pathway and replicates in the endoplasmic reticulum of nonprofessional phagocytes. Infect Immun. 1998;66:5711-24.

16. El-Tras WF, Tayel AA, Eltholth MM, Guitian J. Brucella infection in fresh water fish: evidence for natural infection of Nile catfish, Clarias gariepinus, with Brucella melitensis. Vet Microbiol. 2010;141:321-5.

17. Dawson CE, Perrett LL, Stubberfield EJ, Stack JA, Farrelly SSJ, Cooley WA, et al. Isolation and characterization of Brucella from the lungworms of a harbor porpise (Phocoena phocoena). JWildl Dis. 2008:44:237-46.

18. Garner MM, Lambourn DM, Jeffries SJ, Hall PB, Rhyan JC, Ewalt DR, et al. Evidence of Brucella infection in Parafilaroides lungworms in a Pacific harbor seal (Phoca vitulina richardsi). J Vet Diagn Invest. 1997;9:298-303.

19. Goenka R, Guirnalda PD, Black SJ, Baldwin CL. B lymphocytes provide an infection niche for intracellular bacterium Brucella abortus. J Infect Dis. 2012;206:91-8.

20. Saldana MR, Santelises MA, Lafont MM, Argumedo LS, Cervantes VP, Santiago RL. Human B cells are targets for Brucella abortus infection. J Immunol. 2013;190 Meeting abstract suppl:186.
21. Burns JM, Lestyk KC, Folkow LP, Hammill MO, Blix AS. Size and distribution of oxygen stores in harp and hooded seals from birth to maturity. J Comp Physiol B. 2007;177:687-700.

22. Vitry MA, Hanot MD, Deghelt M, Hack K, Machelart A, Lhomme F, et al. Brucella melitensis invades murine erythrocytes during infection. Infect Immun. 2014;82:3927-38.

23. Nymo IH, Tryland M, Frie AK, Haug T, Foster G, Rodven R, et al. Agedependent prevalence of anti-Brucella antibodies in hooded seals (Cystophora cristata). Dis Aquat Organ. 2013;106:187-96.

24. Lambourn D, Garner M, Ewalt D, Raverty S, Sidor I, Jeffries SJ, et al. Brucella pinnipedialis infections in Pacific Harbor Seals (Phoca Vitulina Richardsi) from Washington State, Usa. J Wildl Dis. 2013;49:802-15.

25. Zarnke RL, Saliki JT, MacMillan AP, Brew SD, Dawson CE, Hoef JMV, et al. Serologic survey for Brucella spp., phocid herpesvirus-1, phocid herpesvirus-2, and phocine distemper virus in harbor seals from Alaska, 1976-1999. J Wildl Dis. 2006;42:290-300.

\section{Submit your next manuscript to BioMed Central and we will help you at every step:}

- We accept pre-submission inquiries

- Our selector tool helps you to find the most relevant journal

- We provide round the clock customer support

- Convenient online submission

- Thorough peer review

- Inclusion in PubMed and all major indexing services

- Maximum visibility for your research

Submit your manuscript at www.biomedcentral.com/submit
() Biomed Central 